\title{
PEMANFAATAN OPEN JURNAL SYSTEM (OJS) UNTUK PENGELOLAAN JURNAL LUMBUNG DI POLITEKNIK PERTANIAN NEGERI PAYAKUMBUH
}

\author{
Amrizal $^{1}$ \\ ${ }^{1}$ Jurusan Teknologi Pertanian, Politeknik Pertanian Negeri Payakumbuh \\ Jl. Raya Negara Km. 7 Tanjung Pati, 26271, Payakumbuh \\ Korespondensi: amrizal.ch@gmail.com
}

$\begin{array}{ll}\text { Diterima } & : \text { 20 Februari } 2018 \\ \text { Disetujui } & : 16 \text { Maret } 2018 \\ \text { Diterbitkan } & : 15 \text { Juli } 2018\end{array}$

\begin{abstract}
ABSTRAK
Open Journal System atau OJS adalah sebuah Content Management System berbasis web yang khusus dibuat untuk menangani keseluruhan prosesmanajemen publikasi ilmiah dari proses call for paper, peer review, hingga penerbitan dalam bentuk online. Politeknik Pertanian Negeri Payakumbuh memiliki satu jurnal yaitu LUMBUNG yang dikelola oleh Pusat Penelitian dan Pengabdian Kepada Masyarakat (P3M). Jurnal Lumbung diterbitkan dalam edisi cetak karena belum memiliki system untuk publikasi secara online. Kelemahan dari sistem penerbitan yang masih manual ini bisa diatasi dengan mengimplemtasikan sistem penerbitan secara elektronik menggunakan Open Jurnal System (OJS) yang bisa dikelola dan diakses secara online. Penerbitan jurnal menggunakan OJS mesti mengacu kepada standar operasional prosedur (SOP) pada OJS yang sudah ditetapakan dimana beberapa aktor yang terlibat didalam penernbnitan jurnal pada system OJS diaantaranya adalah Manager Jurnal, Editor, Author dan Reviewer.
\end{abstract}

Keywords: Jurnal, Lumbung, Open Jurnal System, OJS

\begin{abstract}
The Open Journal System or OJS is a web-based Content Management System specifically used for process papers, peer reviews, and intellectuals in online forms. Payakumbuh State Polytechnic has one journal, LUMBUNG, which is managed by Pusat Penelitian dan Pengabdian Kepada Masyarakat (P3M). The Lumbung Journal is published in the printed edition because it does not yet have a system for online publication. The weakness of the system used can still be overcome by implementing the system electronically using the Open Journal System (OJS) which can be used online. Writing a journal using OJS must be a standard operating procedure (SOP) in OJS that has been established where several actors involved in the journal on his OJS system include Journal Managers, Editors, Authors and Reviewer.
\end{abstract}

Keywords: Journal, Lumbung, Open Journal System, OJS 


\section{PENDAHULUAN}

OJS dikeluarkan oleh Public Knowledge Project dari Simon Fraser University dan berlisensi GNU General Public License (Zuchri, 2009). OJS dapat mengotomatisasikan proses pengiriman artikel, editing, review dan lain-lain yang terkait dengan pengelolaan jurnal. Perangkat lunak yang digunakan pada OJS merupakan perangkat lunak open source untuk mengelola dan menerbitkan jurnal ilmiah secara online. OJS juga merupakan aplikasi yang dapat dioperasikan secara fleksibel dalam manajemen jurnal dan sistem penerbitan jurnal. Aplikasi ini telah dirancang untuk mengurangi waktu dan energi yang diperlukan untuk tugas-tugas administrasi dan manajerial yang berhubungan dengan publikasi jurnal, sekaligus meningkatkan pencatatan serta efisiensi proses editorial. Aplikasi ini berusaha untuk meningkatkan kualitas ilmiah dan publikasi penerbitan jurnal melalui sejumlah inovasi, dari mulai pembuatan kebijakan jurnal yang lebih transparan serta manajemen jurnal yang berbasis online sehingga dapat lebih bermanfaat untuk masyarakat luas yang membutuhkan.

Untuk mengelola jurnal menggunakan OJS yang perlu diperhatikan adalah peran pengguna (Nugroho, 2010), yaitu. (1) Manajer Jurnal, Sebagai pengelola jurnal berhak atas pengaturan kelengkapan, kebijakan, proses pengiriman artikel, pengaturan jurnal, pengaturan tampilan. (2). Manajer Langganan Berperan dalam pengaturan jurnal yang dilanggan. (3). Editors, Memulai aplikasi, proses pengiriman artikel, menetapkan status artikel, mengatur edisi, membuat edisi baru, dan mempublikasikannya, mengirimkan notifikasi kepada pengguna. (4). Editor Bagian, Menetapkan reviewers, bekerjasama dengan para reviewers, membuat keputusan tentang artikel yang akan diterbitkan, copyediting, layoutediting, dan mengoreksi artikel (proofreaders). (5). Reviewer, Meninjau artikel yang dikirimkan, dan berhak mengunggah lampiran yang akan digunakan oleh editor dan author, reviewer ditentukan oleh sectioneditors sesuai dengan kebijakan yang ditetapkan oleh pengelola jurnal. (6). Copy Editors, Berperan dalam melakukan penyuntingan artikel yang dikirimkan dan bekerjasama dengan penulis untuk memperbaiki tata bahasa dan kejelasan isi jurnal serta memastikan aturan penulisan jurnal secara bibliografi dan tekstual sudah sesuai dengan aturan yang ditetapkan sebelum kemudian ditempatkan dalam gallery dan dipublikasikan. (7). Layout Editors, Berperan untuk mengubah format artikel HTML, PDF, DOCX, dan lain-lain sesuai dengan ketentuan jurnal yang telah disepakati. OJS tidak menyediakan 


\section{I.UMIBUNG}

converter otomatis sehingga layout editors harus memiliki perangkat lunak yang dibutuhkan dan melakukannya secara manual kemudian meletakkan file tersebut dalam gallery. (8). Proofreaders, Berperan dalam mengoreksi artikel dalam hal tipografi dan kesalahan format untuk setiap artikel yang tersimpan dalam gallery, kemudian menyerahkan kepada layout editor untuk diperbaiki, peran ini untuk dapat dilakukan oleh editor dan section editor. (9). Penulis, Penulis dapat langsung mendaftarkan diri secara online di halaman website jurnal yang menggunakan OJS dan langsung mengunggah OJS dan langsung mengunggah artikel yang akan dipublikasikan dalam jurnal tersebut dengan terlebih dahulu mengisi metadata atau pengindeksan yang terkait dengan artikel tersebut sehingga dapat dengan mudah dilacak melalui mesin pencari. (10). Pembaca, Pembaca dapat mendaftarkan diri sebagai langganan atau sekedar sebagai pembaca setelah jurnal dapat dibaca secara bebas tanpa biaya. (11). Pelanggan yang mendaftar akan mendapatkan notifikasi untuk setiap jurnal yang dipublikasikan termasuk daftar isi dan jurnal penuh melalui email.

\section{METODE PENELITIAN}

Metode penelitian dalam proses pengelolaan jurnal Lumbung menggunakan perangkat lunak Open Jurnal Sistem mengikuti tahapan penerbitan, mulai dari proses call for paper, peer review, hingga penerbitan dalam bentuk online. Tahap penerbitan seperti terlihat pada Gambar 1. 


\section{I.UMIRUNG}

\section{(1)}

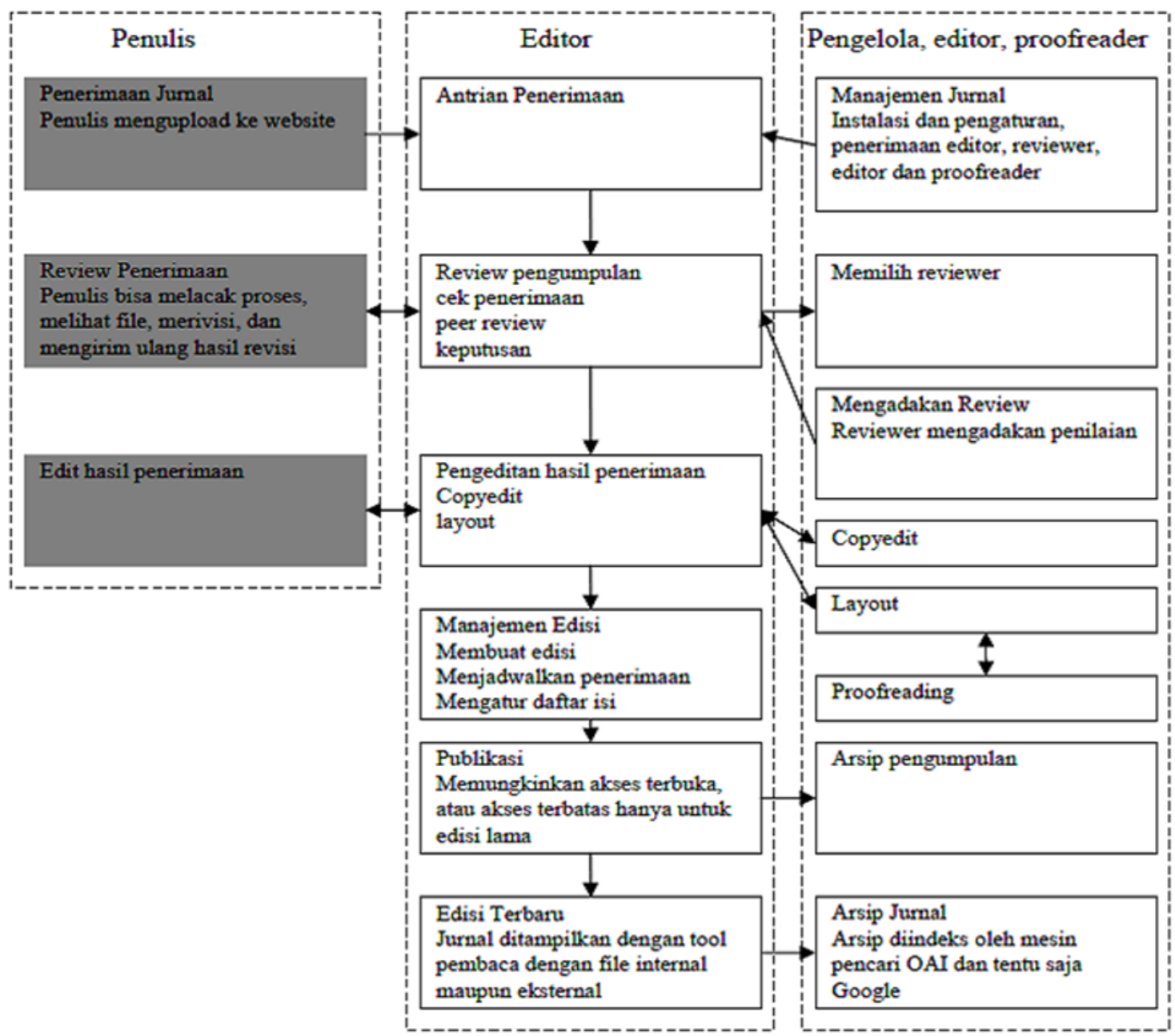

Gambar 1. Proses pengelolaan jurnal Lumbung menggunakan perangkat lunak Open Jurnal Sistem

\section{HASIL DAN PEMBAHASAN}

\section{Tahap Publikasi Jurnal}

Ada beberapa tahapan dalam publikasi jurnal ilmiah dengan menggunakan sistem jurnal online, yaitu proses pengumuman penerimaan naskah, pendaftaran penulis, proses penyerahan naskah dari penulis, proses evaluasi naskah oleh redaksi/editor, proses review oleh reviewer, proses editing oleh editor, proses pembayaran penerbitan naskah oleh penulis dan proses penjadwalan publikasi jurnal online.Proses pengelolaan jurnal online digambarkan dengan flowchart sebagai berikut : 


\section{I.UMIBUNG}

\section{Prosedur Login}

Untuk masuk ke sistem pengguna terlebih malakukan login dengan username dan password yang dimiliki.

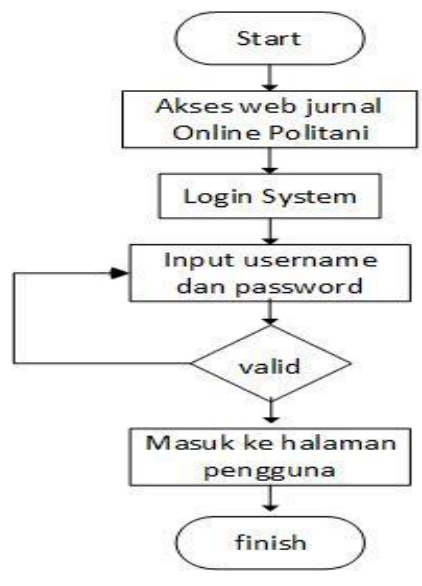

\section{Prosedur submit artikel}

Setelah melalukan login kedalam system untuk melakukan submit artikel pada laman pengguna mengaktifkan link "penyerahan naskah baru", kemudian akan diarahkan ke halaman penyerahan dimana pada bagian ini penulis akan melakukan beberapa tahap (1) penyerahan cekhlist, (2) upload file artikel, (3) pengisian meta ata artikel, (4) upload file pendukung (optional), (5) konfirmasi penyerahan.

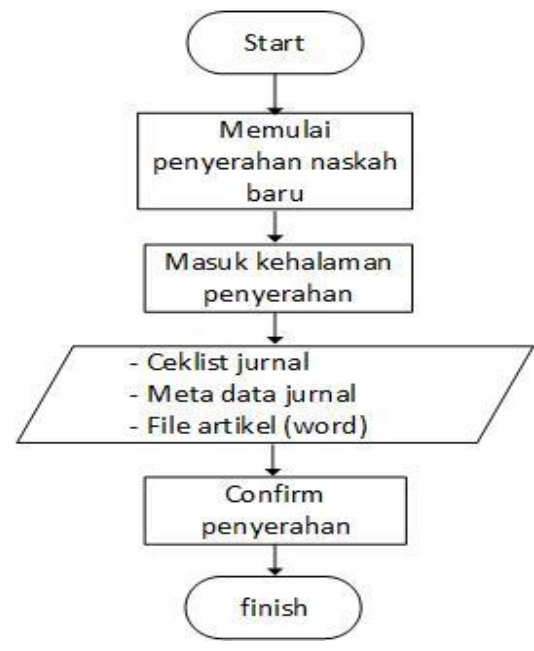

\section{Prosedur penanganan artikel masuk}

Prosedur dimulai dengan Editor menerima notif artikel massuk melalui email notifikasi otomatis dari sistem tentang adanya artikel masuk, selanjutnya Editor malakukan login ke sistem, pada beranda Admin kemudian masuk ke halaman 


\section{I.UMIBUNG}

penyerahan dan memilih artikel masuk yang akan diproses, selanjutnya Editor akan melakukan pengecekan atas artikel dengan cara men-download file artikel, jika artikel telah sesuai Editor akan memulai proses review dengan menugaskan seorang Reviewer yang secara otomatis akan merubah status artikel Penulis menjadi dalam tahap "Review", dan jika tidak editor akan menolak artikel dengan alasan artikel belum sesuai dengan ketentuan jurnal. Pada saat Editor menugaskan seorang Reviewer email otomatis akan terkirim ke email Reviewer yang dituju untuk menginformasikan adanya tugas review artikel baru.

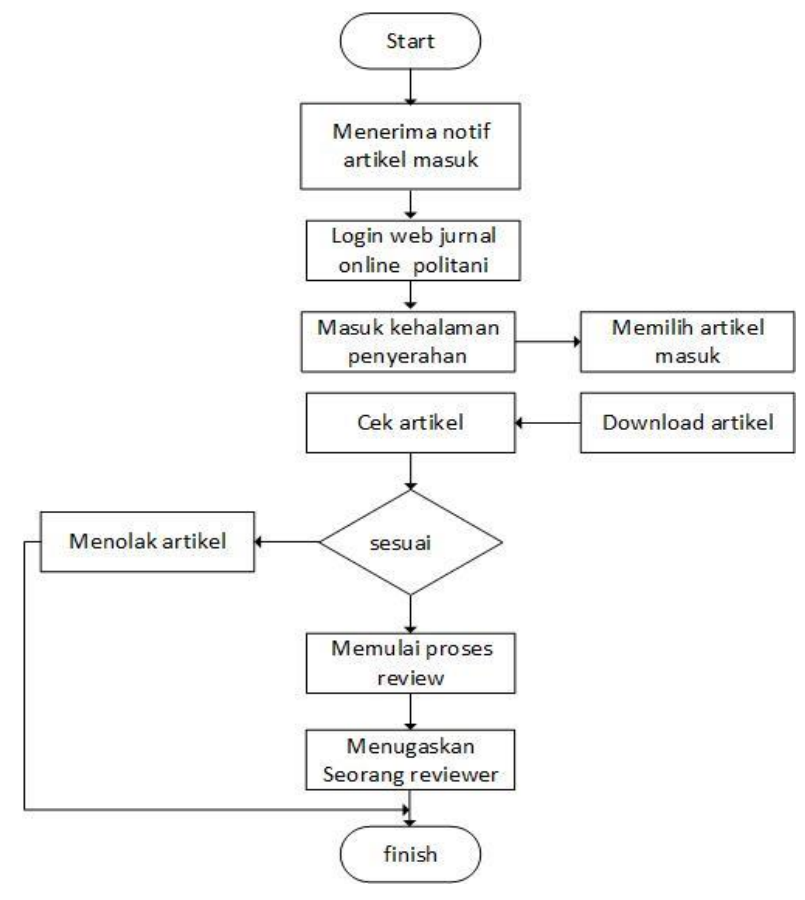

\section{Prosedur Reviwer Artikel}

Prosedur review artikel dimulai dengan Reviewer yang menerima notifikasi email atas tugas review yang diberikan Editor, selanjutnya Reviewer melakukan login ke siste, pada halaman beranda Reviewer tepatnya pada bagian review akan ada artikel aktif yang harus ditangani, kemudian Reviewer akan masuk ke halaman review artikel dan memilih artikel. Pada halaman artikel selanjutnya Reviewer akan dihadapkan dengan pilihan akan menerima tugas atau tidak, jika tidak email notifikasi penolakan tugas akan terkirim ke email Editor dan jika iya maka Reviewer akan memulai tugas review dengan men-download file artikel dan melakukan review artikel. Selanjutnya Reviewer akan memberikan penilaian review dan membuat keputusan atas artikel baik 


\section{I.UMIBUNG}

itu diterima, ditolak, atau permintaan revisi yang akan secara otomatis akan disampaikan ke Editor melalui email otomatis.

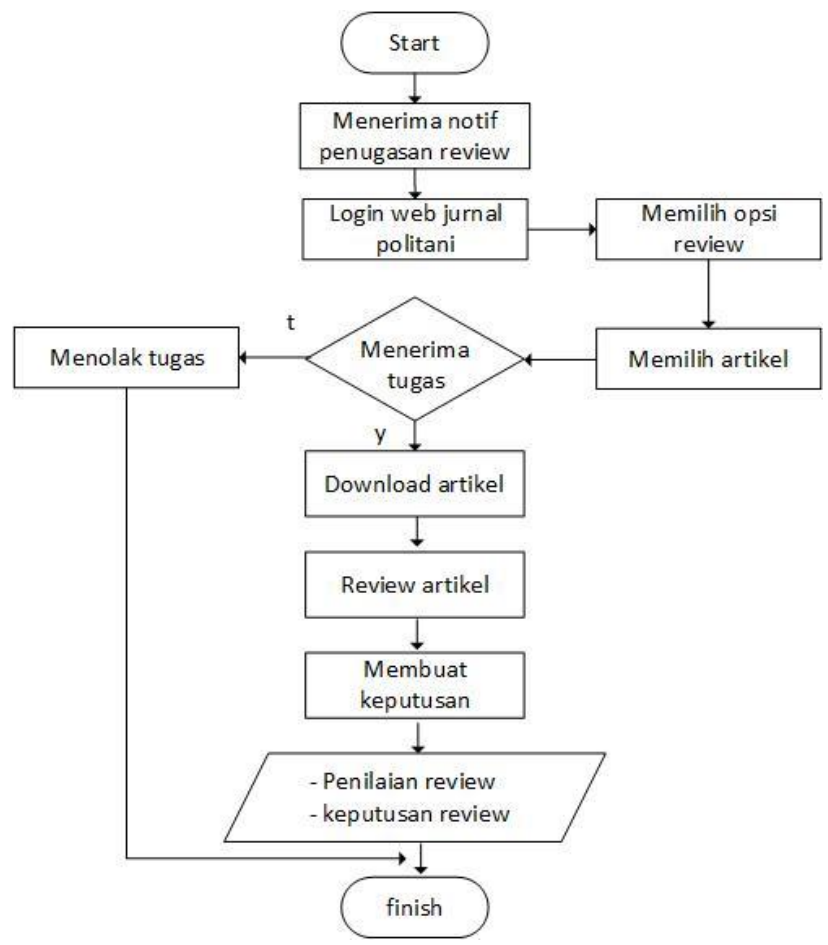

\section{Prosedur Penyimpanan hasil Review}

Prosedur penyampaian hasil review proses dimulai dari Editor yang menerima notifikasi hasil review dari Reviewer yang selanjutnya diproses oleh Editor dengan login ke sistem kemudian pada masuk ke halaman artikel yang dimaksud dan merekam keputusan tersebut dan pada saat dari proses perekaman keputusan oleh Editor tersebut akan mengirimkan juga sebuah email notifikasi ke Penulis atas hasil dari review artikelnya

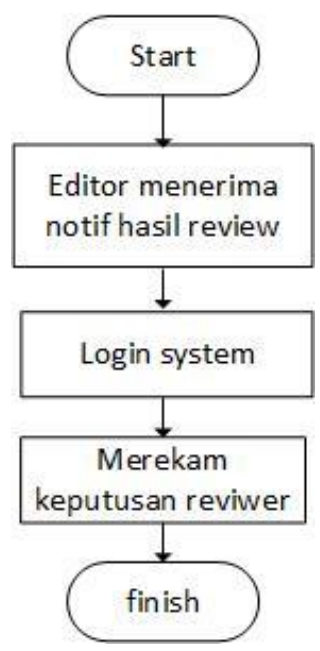




\section{I.UMIBUNG}

\section{Prosedur Upload Revisi}

Prosedur upload revisi yang dilakukan oleh Penulis, dimana pada gambar diatas proses dimulai saat Penulis menerima notifikasi email atas keputusan review artikelnya yang dari keputusan itu akan memiliki 3 buah kemungkinan yaitu "Ditolak", "Diterima", dan "Revisi". Keputusan Ditolak sekaligus menghentikan proses artikel Penulis ke tahap selanjutnya dengan kata lain artikel tidak akan diproses kembali, Diterima berarti status artikel akan dipindahkan ke tahap edioring untuk diterbitkan, dan Revisi adalah status untuk meminta Penulis mengirimkan naskah perbaikan (revisi) sesuai permintaan dimana prosesnya sendiri dimulai dengan Penulis melakukan login ke sistem dan masuk ke halaman review artikelnya kemudian melakukan upload file revisi pada bagian versi revisi yang secara otomatis akan mengirimkan notifikasi kepada Editor bahwa Penulis telah mengirimkan revisiannya

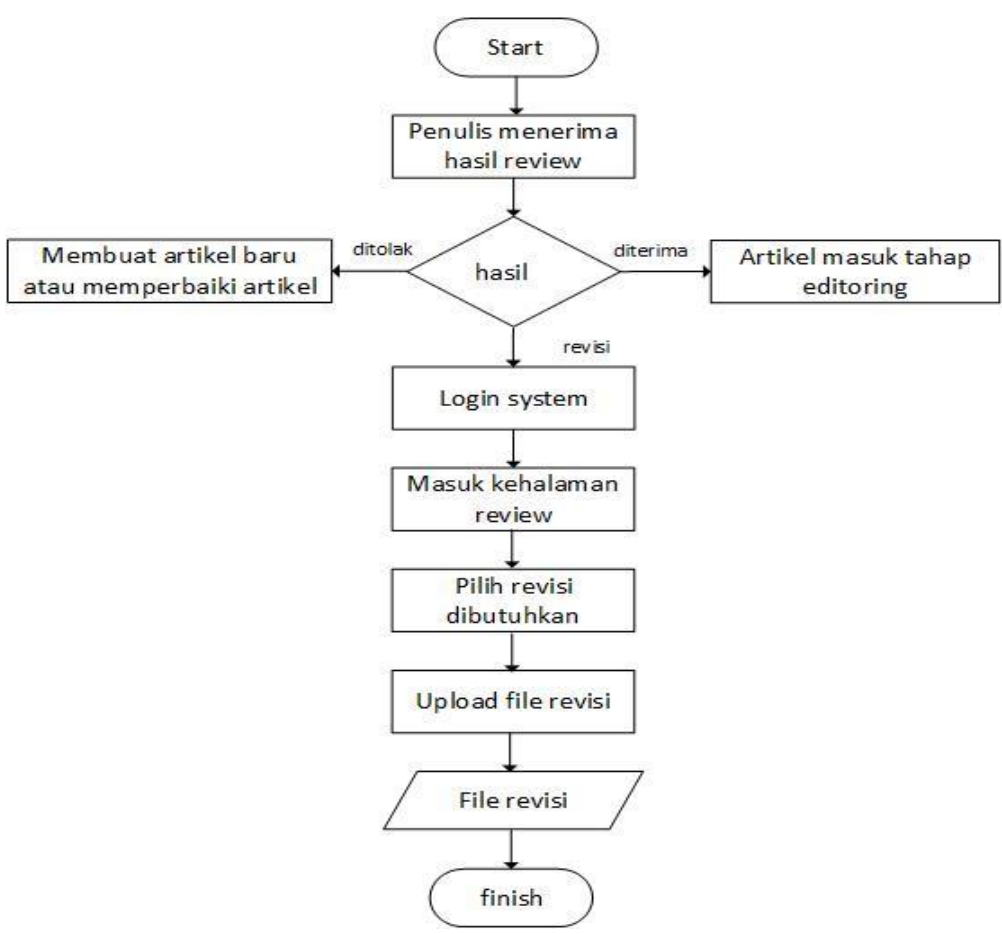

\section{Prosedur Publikasi Jurnal}

Pubikasi jurnal sama halnya seperti sistem penerbitan jurnal konvensional suatu artikel yang akan diterbitkan haruslah lolos tahap "Review" juga telah mengalami proses editoring atau penyesuaian tata layout artikelhingga artikel siap (dalam hal ini talah berformat PDF). Artikel-artikel yang telah siap selanjutnya akan disusun oleh Editor kedalam satu issue jurnal atau terbitan.Saat semua artikel telah dimuat dalam issue jurnal Editor akan menetapkan waktu terbitan dan melakukan publish jurnal yang 


\section{I.UMIBUNG}

bersamaan dengan itu akan mengirimkan notifikasi kepada Penulis dan Pembaca bahwa jurnal telah terbit.

\section{Implemetnasi System}

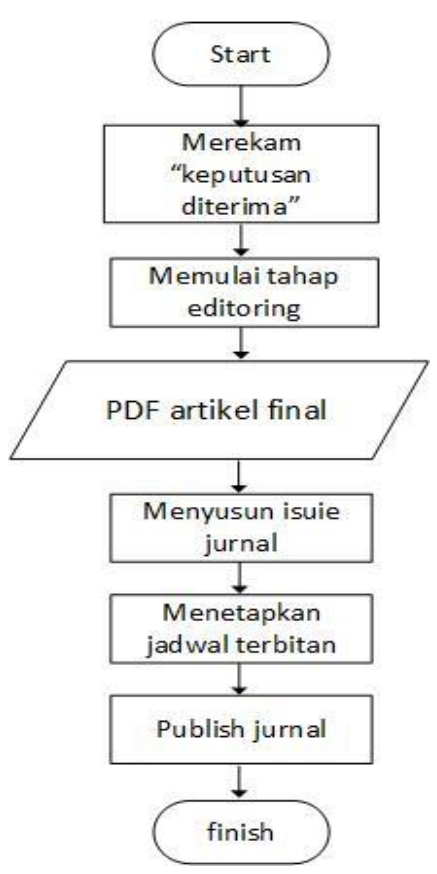

Login System jurnal online lumbung

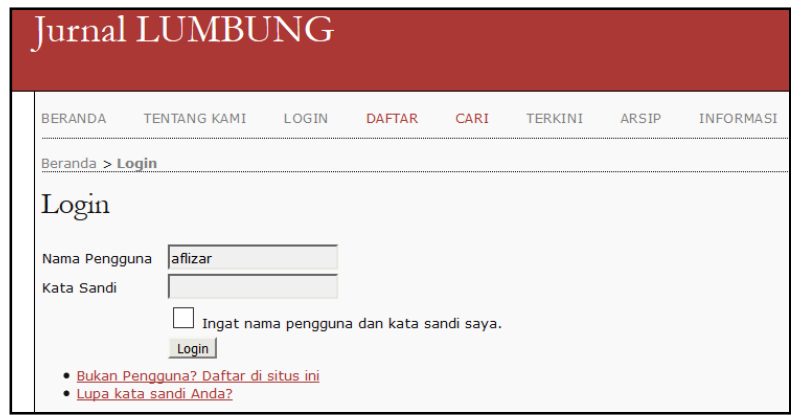

Laman penulis pengusulan penyerahan naskah pada jurnal lumbung :

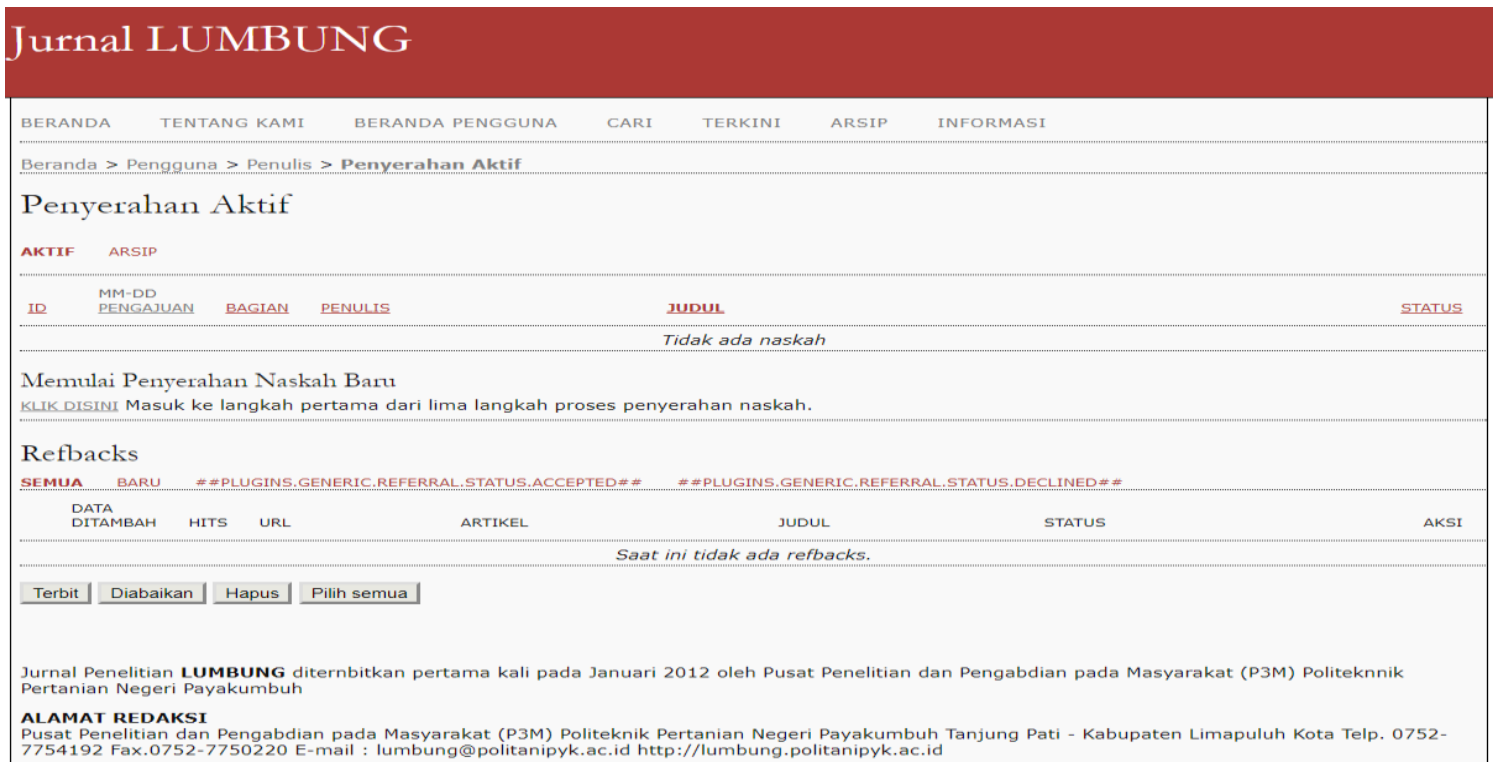




\section{I.UMIBUNG}

Tahap penyerahan naskah pada jurnal lumbung

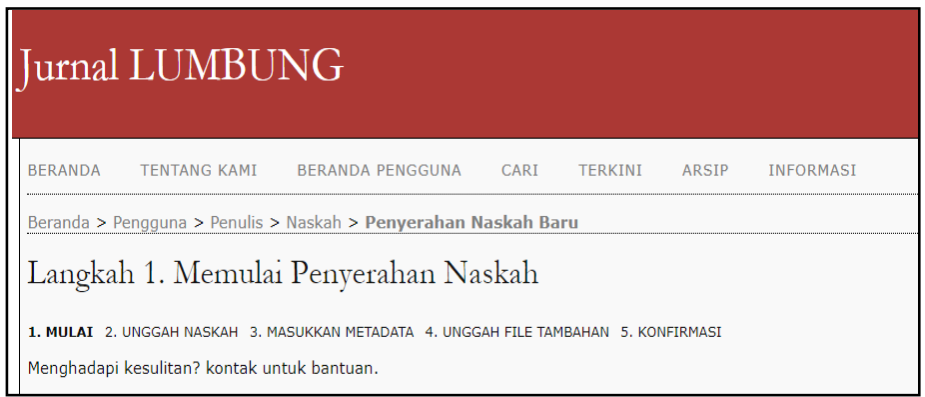

\section{KESIMPULAN}

\section{Kesimpulan}

Dengan menggunakan Open Journal System (OJS) sebagai pengelolaan jurnal dapat dilakukan secara online, dimana semua proses mulai dari penyerahan naskah, review, editoring, hingga publikasi semuanya dapat dilakukan pada satu media yang sama hingga dapat menghasilkan keluaran sebuah jurnal elektronik atau e-journal.

\section{Saran}

Pengelolaan jurnal lumbung yang selama ini masih menggunakan cara manual, sudah saatnya menggunakan system yang terpadu di dalam proses pengeloaan jurnal mulai dari proses penerimaan naskah sampai proses penerbitan. Open Jurnal System (OJS) adalah system yang tepat untuk digunakan sebagai media pengelolan jurnal yang terstuktur.

\section{REFERENSI}

LIPI, 2005. Jurnal Online. [Online] Available at: http://www.jurnal.lipi.go.id/[Accessed 30/03/2014].

Dirjen Dikti, Kemendiknas RI, Januari 2012, Surat Edaran, Publikasi Karya Ilmiah.

Dirjen Dikti, Kemendiknas RI, Februari 2012, Surat edaran, Panduan Pengelolaan Jurnal Terbitan Berkala Ilmiah Elektronik

Nugroho, A. P., 2010. Panduan Open Journal System Indonesian Journal of Biotechnology. [Online] Available at: http://repo.ugm.ac.id/ekstra/pan 


\section{I.UMIBUNG}

duan/OJS/panduan-open-journal-system-biotechnology.pdf

[Accessed: 30/03/2014].

PKP, 2012, Public Knowledge Project, Open Journal Systems (OJS), Simon Fraser University

Surjono, H. D., 2009. Pengenalan dan Pengembangan E-Journal. [Online] Available at: http://blog.uny.ac.id/hermansurjono/files/2009/09/Pengembangan-e-journalherman-d-surjono-uny.pdf [Accessed 30/03/2014].

Tresnawan, A., 2005. Jurnal Elektronik: berbagi pengalaman proses berlangganan jurnal on-line di UPT Perpustakaan UNISBA. [Online] Available at: https://www.scribd.com/doc/138059781/e-Jurnal-doc[Accessed 30/03/2014].

Zuchri, L., 2009. Open Journal Systems: Solusi Pengelolaan Jurnal Ilmiah. [Online] Available at: http://ilmukomputer.org/wp-content/uploads/2009/05/zuchri-ojssolusi-pengelolaan-jurnal-ilmiah.pdf [Accessed 30/03/2014] 